\title{
Z-ligustilide and anti-inflammatory prostaglandins have common biological properties in macrophages and leukocytes
}

\author{
Joseph Schwager ${ }^{*}$, Lidia Gagno, Nathalie Richard, Werner Simon, Peter Weber and Igor Bendik
}

\begin{abstract}
Background: During inflammation, immune cells produce cytokines, chemokines and prostaglandins. This results in acute or chronic inflammation, which favor the development of degenerative diseases such as diabetes, obesity or cardiovascular diseases. Inflammatory processes are modulated by intrinsic and external factors. External factors are supposed to act via similar modes of action as do endogenous molecules and mediators. Both endogenous ligands and nutrient-derived metabolites might modify the extent and status of the cellular and systemic response during inflammation. Therefore, the biological activity of endogenous mediators was compared with nutrition-derived substances.

Methods: Murine macrophages (RAW264.7 cells), in vitro differentiated human promyeloid THP-1 cells and peripheral blood leukocytes (PBL) were stimulated with LPS in the presence of z-ligustilide (LIG) or the endogenous PPARY ligand 15deoxy $\Delta 12,14$-prostaglandin $J_{2}\left(15 d-P G J_{2}\right)$. Secretion of mediators of inflammation was measured by EIA, the Griess reaction and multiplex ELISA (Luminex $\left.{ }^{\circledast}\right)$. Gene expression was quantified by real-time PCR. Nuclear translocation of NF-KB was measured by cytometric techniques.
\end{abstract}

Results: LPS-activated RAW264.7 cells produced nitric oxide (NO), COX2-dependent prostaglandin $E_{2}\left(P_{G} E_{2}\right)$, interleukins and chemokines. LIG concentration-dependently reduced the production of nitric oxide (NO) and PGE 2 , although it did not match the inhibitory potential of $15 \mathrm{~d}-\mathrm{PGJ} \mathrm{J}_{2}$. LIG inhibited the secretion of cytokines (IL-1a, IL-6, TNF-a) and differentiation factors (GM-CSF) in murine macrophages. It blunted the production of CCL2/MCP-1, but did not alter the secretion of CCL5/RANTES. LIG reduced mRNA levels of pro-inflammatory cytokines (e.g. TNF-a, IL-1a, IL-6), chemokines (CCL4/MIP-1 $\beta$ ), and pro-inflammatory enzymes (iNOS). Similarly, LIG robustly impaired inflammatory mediators (e.g. CCL2/MCP-1, CCL3-MIP-1a, CCL4/MIP-1 $\beta$, CXCL10/IP-10, IL-12p70, TNF-a) of LPS-activated human THP-1 cells and PBLs. Unexpectedly, it augmented the production of IL-1 $\beta$, IL-6 and GM-CSF in PBLs.

Conclusions: LIG diminished the extent of the inflammatory response measured by the production of different mediators or metabolites (NO, $\mathrm{PGE}_{2}$, interleukins, cytokines, chemokines). LIG acted at the transcriptional level and targeted the NF-kB signaling pathway. Since LIG and the anti-inflammatory prostaglandin $15 \mathrm{~d}-\mathrm{PG} \mathrm{J}_{2}$ share most of the analyzed biological features, we infer that they have similar modes of action. Hence, LIG acts as an anti-inflammatory prostaglandin and modulates cytokine- and chemokine-dependent inflammatory responses.

Keywords: Chemokines, Cytokines, Inflammation, Macrophages, Z-ligustilide, NF-kB pathway, Anti-inflammatory prostaglandins, Peripheral blood leukocytes, THP-1 human monocytic leukemia cells

* Correspondence: jpschwager@gmail.com

DSM Nutritional Products Ltd., Department of Human Nutrition \& Health, P.O. Box 2676, CH-4002 Basel, Switzerland

(c) The Author(s). 2018 Open Access This article is distributed under the terms of the Creative Commons Attribution 4.0 International License (http://creativecommons.org/licenses/by/4.0/), which permits unrestricted use, distribution, and reproduction in any medium, provided you give appropriate credit to the original author(s) and the source, provide a link to the Creative Commons license, and indicate if changes were made. The Creative Commons Public Domain Dedication waiver (http://creativecommons.org/publicdomain/zero/1.0/) applies to the data made available in this article, unless otherwise stated. 


\section{Background}

Inflammatory processes are involved in the etiology of different diseases such as atherosclerosis, diabetes or arthritis. Acute inflammation encompasses distinct phases - initiation, progression and resorption - which are tightly controlled by mediators [1]. Inflammatory stimuli provoke a rapid release of mediators, which trigger the onset of the inflammatory response. Activation and recruitment of cell populations such as macrophages/monocytes or neutrophils are major hallmarks of the systemic response. Eventually, acute inflammation is self-controlled and relies partly on mechanisms similar to those operational during progression $[2,3]$. Conversely, in chronic inflammation some of these events are not contained and provoke prolonged production of mediators with concomitant tissue erosion and pain.

At the molecular level, various transcription factors including NF- $\mathrm{kB}$ and nuclear receptors are involved in the control of acute and chronic inflammation. Peroxisome proliferator-activated receptors (PPAR) regulate inflammatory responses of macrophages; thus natural PPAR ligands modulate macrophage activation [4-6]. Endogenous PPARY ligands are derived from polyunsaturated fatty acids and generated through the action of lipoxygenase and prostaglandin synthase [7, 8]. Oxidized low-density lipoprotein (ox-LDL) and cyclopentenone prostaglandins including 15-deoxy $\Delta 12,14$-prostaglandin $\mathrm{J}_{2}\left(15 \mathrm{~d}-\mathrm{PGJ}_{2}\right)$ were identified as PPAR $\gamma$ ligands with pro-atherogenic and anti-inflammatory properties, respectively [9, 10]. Several studies demonstrated that PPAR $\gamma$-dependent and PPAR $\gamma$-independent mechanisms regulate inflammatory processes [11-15].

This study aimed at identifying natural substances that modulate inflammatory processes and therefore might be of use in preventing associated diseases. Secondary plant metabolites such as EGCG [16] and resveratrol $[17,18]$ were found to bind to PPAR subtypes and thus modulate inflammatory responses. Z-ligustilide (LIG), a phtalide isolated from Ligusticum chuanxiong has antidiabetic and anti-inflammatory properties [19-22] and was identified as putative novel PPAR $\gamma$ ligand [23]. This prompted us to compare the nutrient-based substance and the endogenously produced anti-inflammatory $15 \mathrm{~d}-$ $\mathrm{PGJ}_{2}$. The data demonstrate that LIG and $15 \mathrm{~d}-\mathrm{PGJ} \mathrm{J}_{2}$ share numerous features in modulating the cellular response to inflammatory stimuli and thus confer LIG the properties of an anti-inflammatory prostaglandin.

\section{Methods}

\section{Reagents}

LIG was from MicroSource (Gaylordsville, CT), or was prepared by DSM Nutritional Products; it was also isolated from Ligusticum chuanxiong by Kieselgur column fractionation (Fig. 1a). Its purity was $>98 \%$ (according to the manufacturer's data sheet). 15-deoxy $\Delta 12,14$ prostaglandin $\mathrm{J}_{2}\left(15 \mathrm{~d}-\mathrm{PGJ}_{2}\right)$ was from Cayman Chemicals (Ann Harbor, MI). Rosiglitazone was purchased from Shanco International, Inc. (Hazlet, NJ). L-NAME (L-N ${ }^{\mathrm{G}}$ Nitroarginine methyl ester) was from Sigma, SaintLouis, MO. Compounds were dissolved in DMSO and added to the culture medium concomitantly with the stimulus. Final DMSO concentration was 0.5\%. Lipopolysaccharide (LPS, E. coli serotype 055:B5) and foetal bovine serum (FBS) were from Sigma. Ficoll-Isopaque was from Nycomed Pharma AS (Oslo, Norway). DMEM, RPMI Medium 1640, PBS, non-essential amino acids (NEAA), $\beta$-mercaptoethanol were from Invitrogen (Carlsbad, CA). Human recombinant interferon- $\gamma$ (IFN$\gamma$ ) was from Preprotech EC (London, UK). Primers and probes used in RT-PCR were designed with the Primer Express $^{\mathrm{Tw}}$ program (Applied Biosystems Inc., Foster City, $\mathrm{CA} ;$ ) and synthesized by Sigma.

\section{Cell culture}

RAW264.7 cells were from ATCC (Manassas, VA) and cultured in DMEM supplemented with 10\% FBS, 50 units $/ \mathrm{mL}$ penicillin, $50 \mu \mathrm{g} / \mathrm{mL}$ streptomycin, Lglutamine and non-essential amino acids. Cells were used between passage 10 and 30. For experiments, cells were seeded into 6-well, 12-well or 96-well plates at 2, 1 and $0.05 \times 10^{6}$ cells per well, respectively, and used after 2 days of pre-culture. Cells were starved in complete DMEM medium containing $0.25 \%$ FBS $18 \mathrm{~h}$ before the treatment. Cells were stimulated with LPS $(1 \mu \mathrm{g} / \mathrm{mL})$ for 4-24 $\mathrm{h}$ in phenol-free DMEM containing $0.25 \%$ FBS.

THP-1 cells (obtained from ATCC) were cultured in RPMI 1640 medium supplemented with 10\% FBS, 50 units $/ \mathrm{mL}$ penicillin, $50 \mu \mathrm{g} / \mathrm{mL}$ streptomycin, NEAA and $2 \times 10^{-5} \mathrm{M} \beta$-mercaptoethanol. Cells were treated with $50 \mathrm{nM}$ phorbol myristate acetate for 3 days. Cells were starved overnight in medium containing $0.25 \%$ FBS before being treated. Cells were stimulated with LPS $(1 \mu \mathrm{g} / \mathrm{mL})$ for $2-24 \mathrm{~h}$ in phenol-free RPMI containing $0.25 \%$ FBS.

Blood was obtained from healthy human volunteers. Peripheral blood leukocytes (PBLs) were also isolated from buffy coats obtained from local blood transfusion centers, using the Dextran sedimentation method to remove erythrocytes. Peripheral blood mononuclear cells were isolated by Ficoll-Isopaque gradient centrifugation and cultured in RPMI 1640 medium, supplemented with $0.25 \%$ FBS, NEAA, penicillin / streptomycin $(50 \mathrm{U} / \mathrm{mL} / 50 \mu \mathrm{g} / \mathrm{mL})$, and $5 \times 10^{-5} \mathrm{M} \beta$-mercaptoethanol. Cell viability was determined by the Trypan Blue exclusion test and exceeded $95 \%$. For in vitro cultures, cells were adjusted to $1 \times 10^{6}$ cells $/ \mathrm{mL}$. Peripheral blood leukocytes were stimulated with LPS $(1 \mu \mathrm{g} / \mathrm{mL})$ and IFN- $\gamma(20 \mathrm{U} / \mathrm{mL})$ for $2-24 \mathrm{~h}$ in phenol-free RPMI containing 0.25\% FBS. 

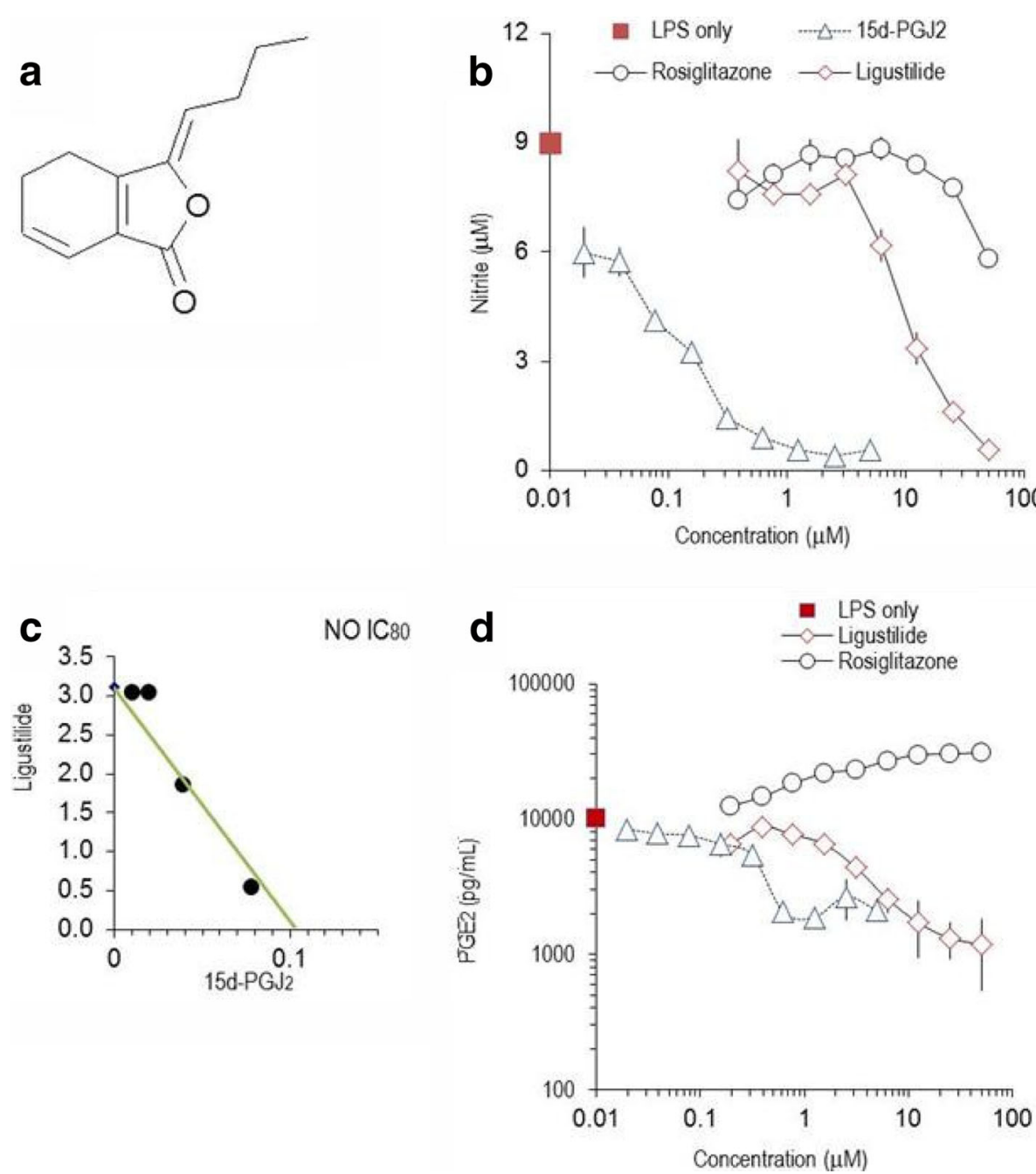

Fig. 1 Z-ligustilide and 15d-PGJ 2 alter nitric oxide and PGE 2 in LPS-activated RAW264.7 cells. a: Molecular structure of z-ligustilide. b: Effect of zligustilide, 15d-PGJ2 and rosiglitazone on the production of nitric oxide (NO, measured as nitrite) by LPS-stimulated RAW264.7 cells, which were cultured for $24 \mathrm{~h}$. Mean values ( \pm SEM) of triplicate cultures from three independent experimental series are shown. c: Interactions between zligustilide and 15d-PGJ2 displayed in an isobologram (for details see reference [26] and Materials and Methods). A straight line was drawn between the $I C_{80}$ value for $z$-ligustilide (in the absence of $15 d-P G J_{2}$ ) and the $I C_{80}$ value of $15 d-P G J_{2}$ (in the absence of $z$-ligustilide). The values of the substances in combination fall on the straight line and thus reflect additive effects between z-ligustilide and $15 \mathrm{~d}-\mathrm{PGJ} \mathrm{J}_{2}$. d: Inhibition of $\mathrm{PGE} \mathrm{E}_{2}$ production by $15 \mathrm{~d}-\mathrm{PG} \mathrm{J}_{2}$, z-ligustilide and rosiglitazone in LPS-stimulated RAW264.7 cells which were cultured for $24 \mathrm{~h}$. PGE 2 was measured by EIA. Mean values \pm SD of triplicates are shown. Similar results were obtained in 3 independent experimental series. Note the logarithmic scale of the axes

\section{Measurements of cell viability}

LDH was determined in supernatants from cell cultures immediately after harvesting, using a commercially available cytotoxicity kit (Promega, Madison, WI).

\section{Measurement of production of $\mathrm{PGE}_{2}$ and NO}

Concentrations of nitrite, which is generated from cellreleased nitric oxide, were determined by the Griess reaction [24]. $\mathrm{PGE}_{2}$ was quantified by EIA [25] according to the manufacturer's instructions (Cayman Chemicals). All determinations were done in duplicates and at various dilutions of the culture supernatants.

\section{Isobolographic analysis of interaction between substances}

The interactions between substances were evaluated using isobologram analysis essentially as described [26]: LIG and 15-PGJ ${ }_{2}$ were mixed at a fixed ratio, added to RAW264.7 cells at a large concentration range and their effects on LPS-induced $\mathrm{NO}$ and $\mathrm{PGE}_{2}$ production determined and expressed as $\mathrm{IC}_{50}$; concomitantly, effect of each individual substance was measured. Alternatively, to cultures containing a given concentration of LIG, $15 \mathrm{~d}-\mathrm{PGJ}_{2}$ was added at varying concentrations and the $\mathrm{IC}_{50}$ or $\mathrm{IC}_{80}$ was computed for the mixture of substances. The $\mathrm{IC}_{80}$ values were then used to create 
isobolograms as described [26, 27]. Synergistic effects were also computed with the CalcuSyn Version 2.0 software (Biosoft, Ferguson, MO).

\section{Determination of cytokine and chemokine production} Multiparametric kits were obtained from BIO-RAD Laboratories (Hercules, CA) and used in the LiquiChip Workstation IS200 (Qiagen, Hilden, Germany) according to the manufacturers' instructions. We used the Bio-Plex Mouse Cytokine 23-Plex Panel and the Bio-Plex Human Group I cytokine Broad Range 27-Plex Panel; the data were acquired with the Luminex IS 2.3 software and evaluated with the LiquiChip Analyser software provided by Qiagen.

\section{Gene expression analysis}

The isolation of total RNA, reverse transcription and quantitative real-time PCR have been done as described before [28]. The parameters for quantitative PCR and the calculation of fold changes (i.e. the relative expression of genes) are given in ,Gene Expression Analysis Using Taqman Assays' (http://www.thermofisher.com). Expression of 18S RNA was used as internal control (housekeeping gene). Expression values were normalized on the basis of unstimulated cells (where the threshold value is set as 1) and computed as fold changes (based on $2^{-\mathrm{X}}$, where $\mathrm{X}$ returns to threshold value $C_{t}$ of stimulated cells - threshold value $C_{t}$ of unstimulated cells). Primer and probe sequences are given in Additional file 1: Table S1.

\section{Measurements of cytoplasmic/nuclear location of NF-кB}

Cells were grown in 96-well plates and pre-incubated with various concentrations of LIG for $1 \mathrm{~h}$. Cells were activated with LPS $(1 \mu \mathrm{g} / \mathrm{mL})$ for $20 \mathrm{~min}$. Thereafter, cells were washed, fixed and permeabilized as detailed by Ding et al. [29]. Immunostaining for NF-kBp65 was performed using the Cellomics NF- $\mathrm{kB}$ Activation HitKitTM (Thermofisher Scientific Inc., Pittsburgh, PA). Nuclei were counter-stained with Hoechst dye. Immunofluorescence was measured by quantitative cytometric technique, ArrayscanTM, with the Cellomics instrumentation (Cellomics ${ }^{\mathrm{Tm}} \quad$ Inc.) expressed as Mean_CircRingAvgInten (for detail see: Cellomics HCS application guide). All treatments were done in triplicates.

\section{Statistical analysis}

Data were evaluated by statistical tools described previously $[28,30,31]$. A $p$ value $<0.05$ (calculated by using Student's $t$ test or one-way ANOVA) was considered to reflect statistically significant differences. Where appropriate, the Tuckey post-hoc test was applied for multiple comparisons. Statistical analysis was conducted with the SPSS software package, version 23.0.0. (SPSS, Munich, Germany).

\section{Results}

Z-ligustilide inhibits the production of nitric oxide and PGE2 in murine RAW264.7 cells

Macrophages respond to inflammatory stimuli by the exuberant secretion of cytokines, chemokines and other inflammatory mediators or enzymes. LPS-stimulated RAW264.7 cells produced significant quantities of nitric oxide (NO) and $\mathrm{PGE}_{2}$ within $24 \mathrm{~h}$ of culture [24, 25], whereas unstimulated cells produced $>10$-fold less mediators. LIG reduced NO production (Fig. 1b) with $\mathrm{IC}_{50}$ of $12.8 \pm 1.4 \mu \mathrm{M}$ (Table 1). L-nitroso-arginine-methyl ester (L-NAME) or resveratrol revealed to be less potent inhibitors with $\mathrm{IC}_{50}$ of $150 \pm 12 \mu \mathrm{M}$ and $28.5 \pm 1.7 \mu \mathrm{M}$, respectively. $15 \mathrm{~d}-\mathrm{PGJ} \mathrm{J}_{2}$ abrogated NO production at $>2 \mu \mathrm{M}$ $\left(\mathrm{IC}_{50} 2.2 \pm 0.6 \mu \mathrm{M}\right)$. Rosiglitazone only marginally impaired NO production at concentrations $>25 \mu \mathrm{M}$ (Fig. 1b).

In order to test the hypothesis that substances might interact, we stimulated macrophages in the presence of combination of substances and visualized the effects on NO production by isobolographic analysis [26, 27]. LIG combined with $15 \mathrm{~d}-\mathrm{PGJ}_{2}$ led to inhibition curves, which reflected additive interaction as displayed in the isobologram (Fig. 1c). The points were on a straight line and thus indicated additive effects between the substances. Rosiglitazone did not reverse the inhibitory effect of LIG or $15 \mathrm{~d}-\mathrm{PGJ}_{2}$ nor was the effect of the combined compounds cumulative (not shown). Next, we explored the effect of LIG and $15 \mathrm{~d}-\mathrm{PGJ}_{2}$ on $\mathrm{PGE}_{2}$ production by LPS-simulated RAW264.7 cells. LIG (at $>20 \mu \mathrm{M}$ ) abrogated $\mathrm{PGE}_{2}$ production (Fig. 1d), but it was a less potent inhibitor than $15 \mathrm{~d}-\mathrm{PGJ}_{2}\left(\mathrm{IC}_{50}\right.$ of $9.3 \pm 1.6 \mu \mathrm{M}$ and $\mathrm{IC}_{50}$ $2.2 \pm 0.5 \mu \mathrm{M}$, respectively). When the two substances were combined and the inhibitory effect on $\mathrm{PGE}_{2}$ production analyzed, isobologram analysis revealed additive effects similar to those observed on NO production (data not shown). It should be noted that rosiglitazone concentration-dependently increased COX2-dependent $\mathrm{PGE}_{2}$ production (Fig. $1 \mathrm{~d}$ ). LIG and $15 \mathrm{~d}-\mathrm{PGJ}_{2}$ had only insignificant effects in unstimulated cells, which produced $<10 \%$ of mediators secreted after LPS activation.

Table 1 IC 50 values (in $\mu \mathrm{M}$ ) for substances tested in LPS-activated RAW264.7 cells

\begin{tabular}{lllll}
\hline & $\mathrm{PGE}_{2}$ & \multicolumn{3}{c}{ Nitric Oxide } \\
& Mean \pm S.E.M. & $\mathrm{N}$ & Mean \pm S.E.M. & $\mathrm{N}$ \\
\hline Z-ligustilide & $9.3 \pm 1.6$ & 33 & $12.8 \pm 1.4$ & 58 \\
15d-PGJ 2 & $2.2 \pm 0.5$ & 16 & $2.3 \pm 0.6$ & 25 \\
Rosiglitazone & $>50$ & 2 & $26.9 \pm 1.9$ & 16 \\
L-NAME & $>500$ & 2 & $150 \pm 12$ & 2 \\
\hline
\end{tabular}

Cells (in triplicates) were incubated with graded amounts of substances, stimulated with $1 \mu \mathrm{g} / \mathrm{mL}$ LPS and cultured for $24 \mathrm{~h}$. PGE 2 and NO were measured by EIA and the Griess reaction, respectively, and the $\mathrm{IC}_{50}$ values were calculated for each experimental series. $\mathrm{N}$ : number of independent experimental series. L-NAME: L-N ${ }^{G}$-Nitroarginine methyl ester 
We further inspected whether the treatment of cells with compounds affected cell viability. LIG did not exert significant cytotoxic effects within a concentration range of $<100 \mu \mathrm{M}$ (Additional file 1: Figure S1) and was comparable to other micronutrients such as resveratrol or the catechin EGCG, which did not impair cell viability. Similarly, rosiglitazone or $15 \mathrm{~d}-\mathrm{PGJ}_{2}$ had no cytotoxic effects at concentrations $<50 \mu \mathrm{M}$ and $<2.5 \mu \mathrm{M}$, respectively.

\section{Z-ligustilide modulates the inflammatory response in human THP-1 cells and peripheral blood leukocytes} We hypothesized that LIG modulated the production of inflammatory mediators in a similar way in different species. Therefore, THP-1 cells, a human monocytic leukemia cell line, were induced to differentiate in vitro, stimulated with LPS [32] and the effect of substances on eicosanoid synthesis was determined. LIG and $15 \mathrm{~d}-\mathrm{PGJ}_{2}$ blunted $\mathrm{PGE}_{2}$ production, whereas rosiglitazone augmented COX-2 dependent $\mathrm{PGE}_{2}$ levels in THP-1 cells (Fig. 2a). Likewise, human peripheral blood leukocytes (PBLs, consisting of mononuclear and polymorphonuclear cells) were stimulated with LPS/IFN- $\gamma$ in the presence of various concentrations of $\mathrm{LIG}$ and the $\mathrm{PGE}_{2}$ secretion was determined. LIG dose-dependently decreased the inflammatory response as measured by the $\mathrm{PGE}_{2}$ production (Fig. 2b); $15 \mathrm{~d}-\mathrm{PGJ}_{2}$ had stronger inhibitory effects than LIG (not shown). Effects of LIG and $15 \mathrm{~d}-\mathrm{PGJ}_{2}$ on unstimulated cells were not significant. Collectively, murine macrophages and human cell lines or primary cells (PBLs) displayed a similar responsiveness to LIG.
Z-ligustilide alters the production of cytokines, chemokines and differentiation factors secreted by murine macrophages and human peripheral blood leukocytes

Next, we investigated the effect of LIG and $15 \mathrm{~d}-\mathrm{PGJ}_{2}$ on inflammatory proteins produced by murine macrophages. The secretion of 9 (of 14 measured) cytokines and chemokines was increased 4-fold to 4000 -fold in LPS-activated RAW264.7 cells. Among the analyzed differentiation factors and chemokines, LIG concentrationdependently impaired the secretion of GM-CSF, CCL2/ MCP-1 and CCL4/MIP-1 $\beta$; CCL5/RANTES was only affected by high phtalide concentrations $(25 \mu \mathrm{M})$ (Table 2 and Fig. 3). It exerted similar inhibitory effects on IL- $1 \alpha$, IL- 6 and TNF- $\alpha$, whereas IFN- $\gamma$ and IL-12p70 were virtually unaltered. $15 \mathrm{~d}-\mathrm{PGJ}_{2}$ shared with LIG all features of the inhibition pattern, except for GM-CSF, CCL4/ MIP-1 $\alpha$, CCL5/RANTES and TNF- $\alpha$ (Table 2 and Fig. $3)$. It should be noted, however, that the two substances differed in their biological potency: on a stoichiometric basis, $15 \mathrm{~d}-\mathrm{PGJ}_{2}$ was $\sim 10$-fold more efficient than LIG.

We extended this analysis to human PBLs, where the activation with LPS/IFN- $\gamma$ led to $>4$-fold increased secretion of inflammatory proteins, which included chemokines (CCL3/MIP-3 $\alpha$, CXCL8/IL-8, CXCL10/IP-10) and cytokines (TNF- $\alpha$, IL-1 $\beta$, IL-6, IL-12p70). CCL5/RANTES and CCL2/MCP-1 were constituently expressed at high levels presumably by polymorphonuclear cells (PMNL), contained in PBLs. The secretion of GM-CSF, CCL2/MCP-1 and TNF- $\alpha$ was drastically decreased by raising concentrations of LIG (Fig. 4 and Table 3). Conversely, IFN- $\gamma$, CXCL/10IP-10, IL-1 $\beta$, IL-6 and CCL5/RANTES were only marginally influenced. This further revealed that the phtalide specifically affected the secretion of distinct cytokines and chemokines. LIG and $15 \mathrm{~d}-\mathrm{PGJ}_{2}$ differed in two

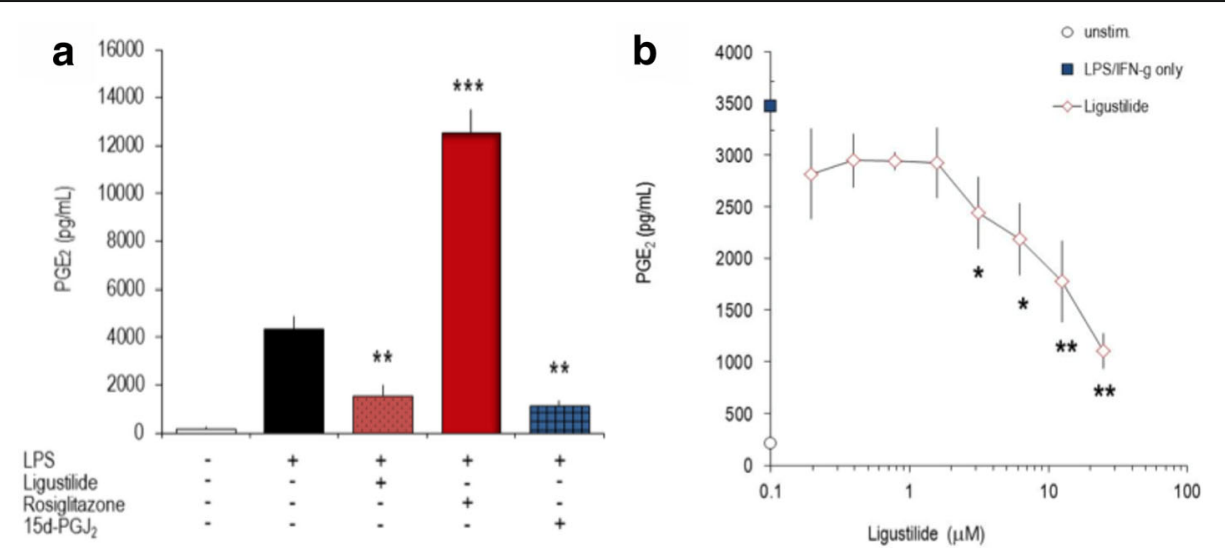

Fig. 2 Z-ligustilide modulates PGE 2 production in human THP-1 cells and PBLs. a: Effect of z-ligustilide, $15 \mathrm{~d}-\mathrm{PGJ} \mathrm{J}_{2}$ and rosiglitazone on THP-1 cells: Cells were differentiated in vitro with phorbol myristate acetate $(20 \mathrm{~nm} / \mathrm{L})$ for 3 days, stimulated with $L P S(1 \mu \mathrm{g} / \mathrm{mL})$ in the absence or presence of z-ligustilide $(25 \mu \mathrm{M})$, rosiglitazone $(25 \mu \mathrm{M})$, or $15 \mathrm{~d}-\mathrm{PG} \mathrm{J}_{2}(2.5 \mu \mathrm{M})$. Secreted $\mathrm{PGE}_{2}$ was determined after $24 \mathrm{~h}$ by EIA. b: Freshly isolated peripheral blood leukocytes were stimulated with LPS/IFN- $\gamma$ in the presence of graded amounts of z- ligustilide. Secreted $\mathrm{PGE}_{2}$ was determined after $24 \mathrm{~h}$ by EIA 
Table 2 Inflammatory proteins secreted by RAW264.7 cells

\begin{tabular}{|c|c|c|c|c|}
\hline Protein & $\begin{array}{l}\text { Secretion by unstimulated } \\
\text { cells }[\mathrm{pg} / \mathrm{mL}]\end{array}$ & $\begin{array}{l}\text { LPS-induced protein secretion } \\
\text { (ratio LPS-stim./unstim.) }\end{array}$ & $\begin{array}{l}\text { \% inhibition by } \\
\text { LIG }(25 \mu \mathrm{M})\end{array}$ & $\begin{array}{l}\text { \% inhibition by } \\
15-d P G J_{2}(1.25 \mu M)\end{array}$ \\
\hline CCL2/MCP-1 & 4005 & 65 & $86 \pm 5^{* * *}$ & $58 \pm 39^{* *}$ \\
\hline CCL4/MIP-1 $\beta$ & 39,250 & 7.0 & $\left.40 \pm 13^{*}\right)$ & $-9 \pm 22$ \\
\hline CCL5/RANTES & 268 & 219 & $61 \pm 4^{* *}$ & $2 \pm 27$ \\
\hline IFN- $\gamma$ & 22 & 4.2 & $32 \pm 3^{* *}$ & $24 \pm 4^{*}$ \\
\hline GM-CSF & 134 & 16 & $94 \pm 5^{* *}$ & $91 \pm 2^{* * *)}$ \\
\hline IL-1a & 9 & 233 & $95 \pm 4^{* * *)}$ & $50 \pm 1^{* *}$ \\
\hline IL-6 & 28 & 1442 & $90 \pm 0^{* * *}$ & $\left.76 \pm 15^{*}\right)$ \\
\hline IL-12p70 & 84 & 4.6 & $38 \pm 2^{* *}$ & $27 \pm 7^{*}$ \\
\hline TNF-a & 40 & 3820 & $68 \pm 5^{* *}$ & $67 \pm 2^{* *}$ \\
\hline
\end{tabular}

RAW264.7 cells were stimulated with LPS and cultured for $24 \mathrm{~h}$ in the presence of substances. Secreted proteins were measured by multiparametric analysis (Luminex technology). The LPS-induced increase of secreted proteins is given as ratio of values obtained in stimulated versus unstimulated cells. ${ }^{*} p<0.05$; ${ }^{* *} p<$ $0.01 ;{ }^{* * *} p<0.005$ ('LPS + substance' treated versus 'LPS-only' treated cells)

important aspects in their anti-inflammatory effects on PBLs: CCL2/MCP-1 and TNF- $\alpha$ production were not impaired by the cyclopentenone prostaglandin, whereas LIG strongly altered them (Fig. 4). It should be noted that GM-CSF and IL-6 secretion was markedly enhanced when LPS/INF- $\gamma$ activated PBLs were treated with LIG or 15d$\mathrm{PGJ}_{2}$. This was substantially more potent than LIG in its biological effects.

Using quantitative real-time PCR technology, we have evaluated the influence of LIG on inflammatory genes. Since macrophages drastically up-regulated inflammatory gene mRNA expression within $1-6 \mathrm{~h}$ following LPS-stimulation, we have chosen to analyze the influence of compounds in cells after $4 \mathrm{~h}$ of culture. There were notable differences in the basal expression levels in unstimulated macrophages with weakly (e.g. COX-2, iNOS, prostaglandin E synthase [PGES], IL-6, IL-1 $\beta$, PPAR 1 1), moderately (e.g. COX-1, prostaglandin EP-2 receptor [EP-2], hematopoietic-type prostaglandin D synthase [PGDS], IL-1 $\alpha$ ) and abundantly expressed genes (e.g. TNF- $\alpha$, fibronectin receptor- $\alpha$ [FNR- $\alpha$, PPAR $\beta$, CCL4/MIP-1 $\beta$ ) (data not shown). LPS induced a substantial increase of mRNA of interleukins and cytokines (e.g. IL-6, IL- $1 \alpha$ and TNF- $\alpha$ ) but also of iNOS and COX-2, whereas other genes were down-regulated (e.g. PGDS, EP-2, PPAR 1) (Fig. 5, Additional file 1: Figure S2). Unlike LIG, 15d-PGJ 2 modulated PPARy expression and shifted it towards pre-homeostatic/inflammatory levels.

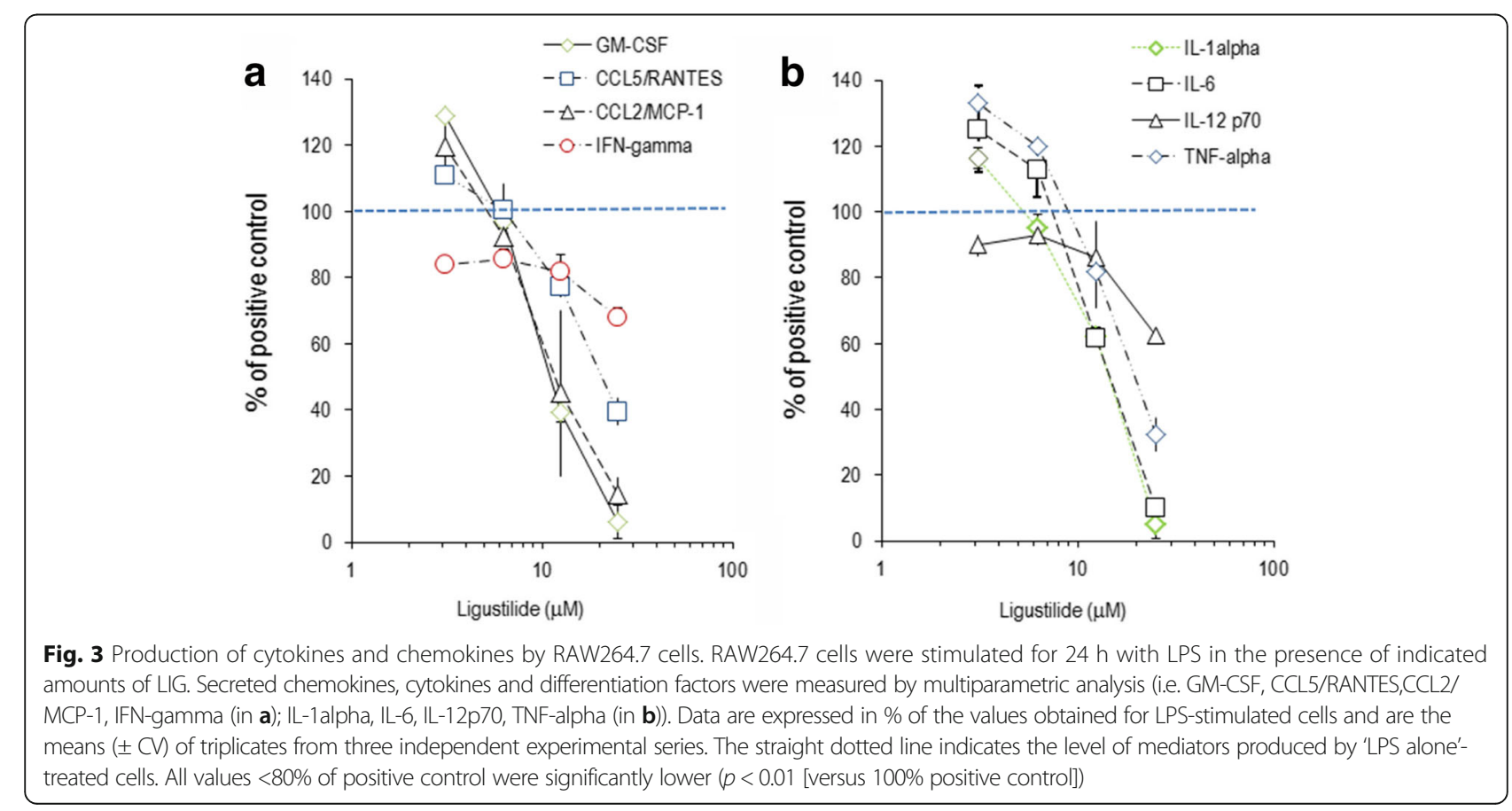



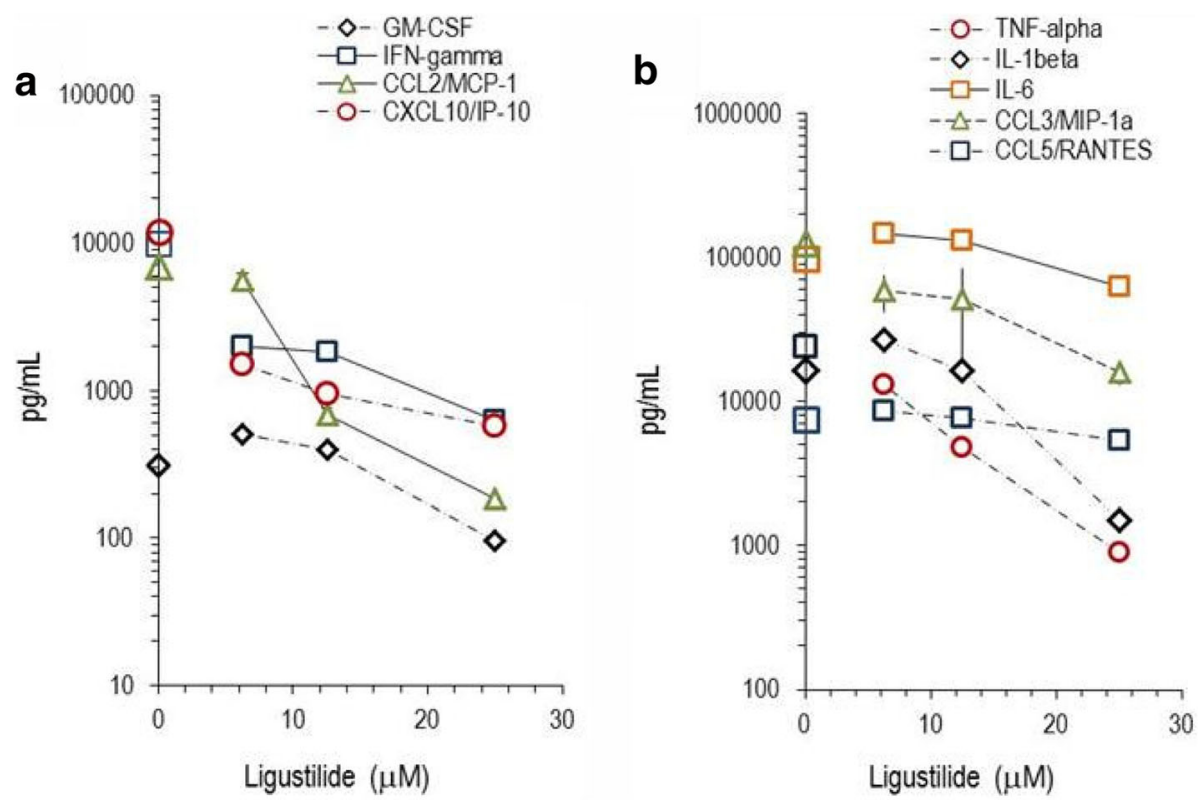

Fig. 4 Production of cytokines and chemokines by PBLs. Freshly isolated peripheral blood leukocytes were stimulated for $24 \mathrm{~h}$ with LPS/INF- $\gamma$ in the presence of indicated amounts of LIG. Secreted chemokines, cytokines and differentiation factors (i.e. GM-CSF, IFN-gamma, CCL2/MCP-1, CXCL10/IP105/RANTES (in a); TNF-alpha, IL-1 beta, IL-6, CCL3/MIP1alpha, CCL5/RANTES (in b)) were measured by multiparametric analysis and are indicated in pg/ $\mathrm{mL}$. 'LPS/INF- $y$ alone' values for the molecules are indicated on the $y$-axis. Data are means \pm SD of triplicate cultures of PBLs

LIG reduced expression levels of iNOS, IL-1 $\alpha$, IL-1 $\beta$, TNF- $\alpha$ and CCL $4 /$ MIP- $1 \beta$ by up to $90 \%$ in the concentration range of $6.25-50 \mu \mathrm{M}$. Interestingly, LPS-inducible COX-2 gene expression did not significantly change in the presence of LIG.

Since the expression of inflammatory genes in macrophages is in part PPAR $\gamma$ dependent $[4,5,15]$, we compared the effects of PPAR ligands like rosiglitazone or $15 \mathrm{~d}-\mathrm{PGJ}_{2}$ with LIG (Fig. 6). LIG (at $25 \mu \mathrm{M}$ ) significantly down-regulated 3 of 10 genes, while it up-regulated
PPAR $\beta$ and the receptor of $\mathrm{PGE}_{2}$ and EP-2 [33]. 15d-PGJ 2 modulated inflammatory gene expression in a similar pattern, as did LIG, yet its effects were substantially stronger. Remarkably, it shifted expression of PPAR 1 and PGDS to base-line homeostasis (Additional file 1: Figure S2). Rosiglitazone shared some features with LIG (and thus also with $15 \mathrm{~d}-\mathrm{PGJ}_{2}$ ), but unlike LIG, it increased the expression of IL-1 $\alpha$, IL- 6 and COX-2. Taken together, in murine macrophages the biological effects of LIG matched those of $15 \mathrm{~d}-\mathrm{PGJ}_{2}$ but differed from rosiglitazone.

Table 3 Inflammatory proteins secreted by human PBLs

\begin{tabular}{|c|c|c|c|c|}
\hline Protein & $\begin{array}{l}\text { Unstimulated cells } 24 \mathrm{~h}) \\
{[\mathrm{pg} / \mathrm{mL}]}\end{array}$ & $\begin{array}{l}\text { Protein secretion } \\
\text { (ratio LPS-stim./ unstim.) }\end{array}$ & $\begin{array}{l}\text { \% inhibition by Lig } \\
(6.25 \mu \mathrm{M})\end{array}$ & $\begin{array}{l}\text { \% inhibition by } 15 d-P G J_{2} \\
(1.25 \mu \mathrm{M})\end{array}$ \\
\hline CCL2/MCP-1 & 8540 & 0.8 & $87 \pm 3^{* *)}$ & $-37 \pm 34$ \\
\hline CCL3/MIP-1a & 6055 & 20.6 & $61 \pm 4^{*}$ & $67 \pm 36^{* *}$ \\
\hline CCL4/MIP-1 $\beta$ & 35,000 & 7.0 & $68 \pm 7^{* *}$ & $\left.51 \pm 14^{*}\right)$ \\
\hline CCL5/RANTES & 9225 & 0.8 & $<2$ & $<2$ \\
\hline CXCL8/IL-8 & 20,700 & 21.1 & $<2$ & $<2$ \\
\hline CXCL10/IP-10 & 529 & 22.6 & $89 \pm 3^{* *}$ & $86 \pm 12^{* *}$ \\
\hline IFN- $\gamma$ & 22 & 10.4 & $84 \pm 1^{* *}$ & $85 \pm 9^{* *}$ \\
\hline TNF-a & 982 & 24.8 & $46 \pm 4^{*}$ & $-16 \pm 18$ \\
\hline$I L-1 \beta$ & 1055 & 15.5 & $\left.-57 \pm 5^{*}\right)$ & $\left.38 \pm 0^{*}\right)$ \\
\hline IL-6 & 11,400 & 8.6 & $-51 \pm 3^{* *}$ & $-135 \pm 32^{* *}$ \\
\hline IL-12p70 & 12 & 21.1 & $89 \pm 2^{* *}$ & $85 \pm 12^{* *}$ \\
\hline
\end{tabular}

Peripheral blood leukocytes were isolated and cultured for $24 \mathrm{~h}$ at the indicated treatments. The proteins secreted into the culture supernatants were measured by multiparametric analysis. * $p<0.05 ;{ }^{* *} p<0.01 ;{ }^{* * *} p<0.005$ ('LPS + substance' treated versus 'LPS-only' treated cells) 

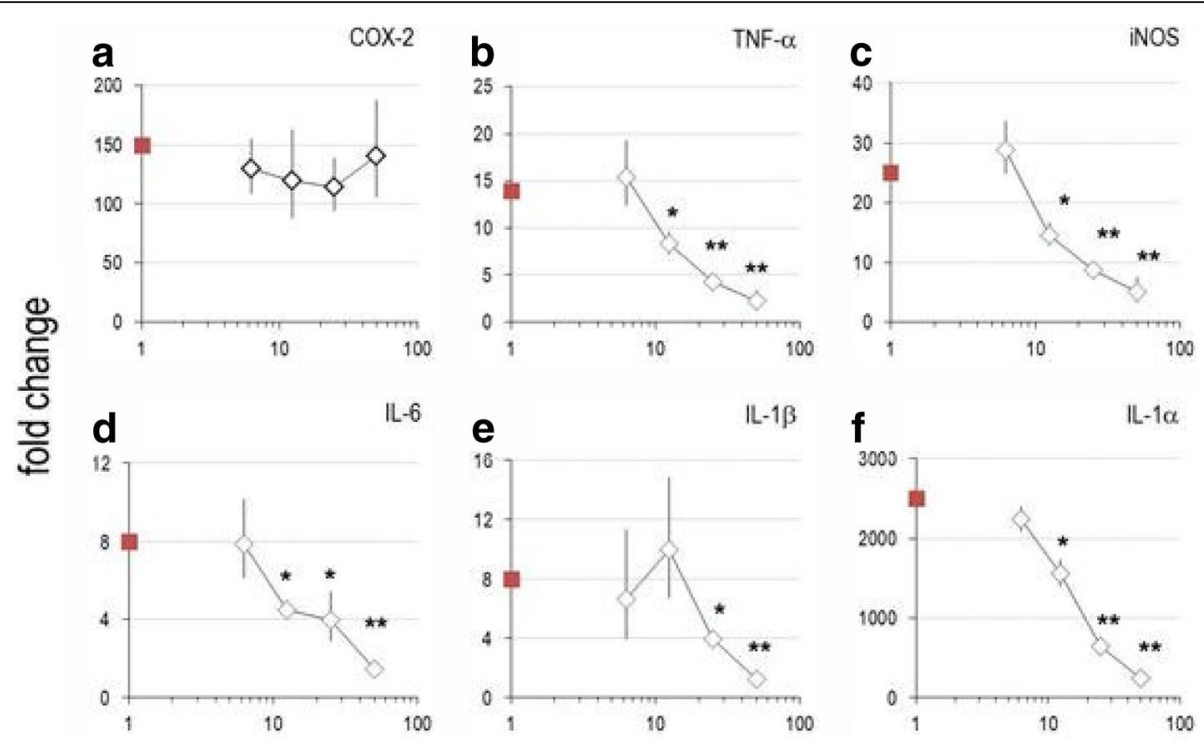

\section{Ligustilide $(\mu \mathrm{M})$}

Fig. 5 Effect of z-ligustilide on inflammatory genes expression of murine macrophages. Unstimulated or LPS-stimulated RAW264.7 cells were cultured for $4 \mathrm{~h}$ in the presence of graded amounts of LIG; mRNA levels were determined by RT-PCR. mRNA levels are indicated as fold change (y axis), which was calculated as indicated in Materials and Methods. Bars represent mean values of fold change $+/-$ errors (see [28]) of triplicates (versus unstimulated cells). ${ }^{*} p<0.05 ;{ }^{* *} p<0.01$ (versus 'LPS alone' stimulated cells). a: COX-2; b: TNF-a; c: iNOS; d: IL-6; e: IL-1ß; f: IL-1a

Z-ligustilide modulates expression of inflammatory genes in human THP-1 cells

Similar to murine macrophages, THP-1 cells responded to LPS stimulation by extensively up-regulated interleukins (IL-1 $\alpha$, IL-6), chemokines (IL-8, CXCL2/MIP-2, CCL20/MIP3 $\alpha$ ) or cytokines (e.g. TNF- $\alpha$ ) (Fig. 7). All three compounds tested altered the gene expression pattern in a similar way, and their effects could be ranked as for RAW264.7 cells (i.e. $15 \mathrm{~d}-\mathrm{PGJ}_{2}>\mathrm{LIG}>$ rosiglitazone). Other genes involved in inflammatory pathways including PPAR $\alpha, 5$-LOX and MMP - 9 were refractory to LIG, $15 \mathrm{~d}-\mathrm{PGJ}_{2}$ and rosiglitazone (data not shown).

\section{Z-ligustilide inhibits nuclear translocation of NF-кBр65}

In order to further detect early effects of LIG on cell activation, the nuclear translocation of NF- $\mathrm{kB}$ during LPS-activation of RAW264.7 cells was measured by quantitative cytometric techniques. Cells responded to stimulation within 20 min by a substantial accumulation of NF-кBp65 in the nucleus; this was reflected by the shift in the ratio of nuclear/cytoplasmic fluorescence as shown in Fig. 8. In cells, which were pre-treated with LIG, the translocation of NF-kBp65 into the nucleus was significantly reduced in a concentration-dependent way.

\section{Discussion}

The coordinated responses to inflammatory stimuli include synthesis and secretion of mediators during the progression of inflammation and its resolution by orchestrated production of endogenous molecules that terminate inflammation. Among these, cyclopentenone prostaglandins, lipoxins, NF- $\mathrm{kB}$ and mediators of apoptosis have recently attracted considerable interest (reviewed in [2]. Any deviation in these fine-tuned interactions can lead to an excessive and uncontrolled response that might result in chronic inflammatory processes. Given the fact that inflammatory responses are vital for the host's appropriate defense against pathogens and external insults, the major challenge relies in the containment of inflammation i.e. its appropriate timing and extent of resolution. In this study, we have shown that LIG behaves to a large extent like antiinflammatory prostaglandins and thus might contribute to the adequate resolution of inflammation as well as to the attenuation of chronic inflammatory processes (Additional file 1: Table S2).

Our experimental approach was instigated by the identification of LIG, a natural substance with anti-diabetic properties [23]. We hypothesized that LIG and PPAR $\gamma$ agonists like rosiglitazone interfere with inflammatory responses in a similar manner and compared their impact on hallmarks of inflammation including the gene expression and production of nitric oxide, $\mathrm{PGE}_{2}$, chemokines, interleukins and cytokines. Whereas rosiglitazone moderately impaired NO production and even enhanced $\mathrm{PGE}_{2}$ secretion, LIG potently diminished the production of both metabolites and performed like $15 \mathrm{~d}-\mathrm{PGJ}_{2}$. Previously, $15 \mathrm{~d}-\mathrm{PGJ}_{2}$ had been identified as a PPAR $\gamma$ ligand 

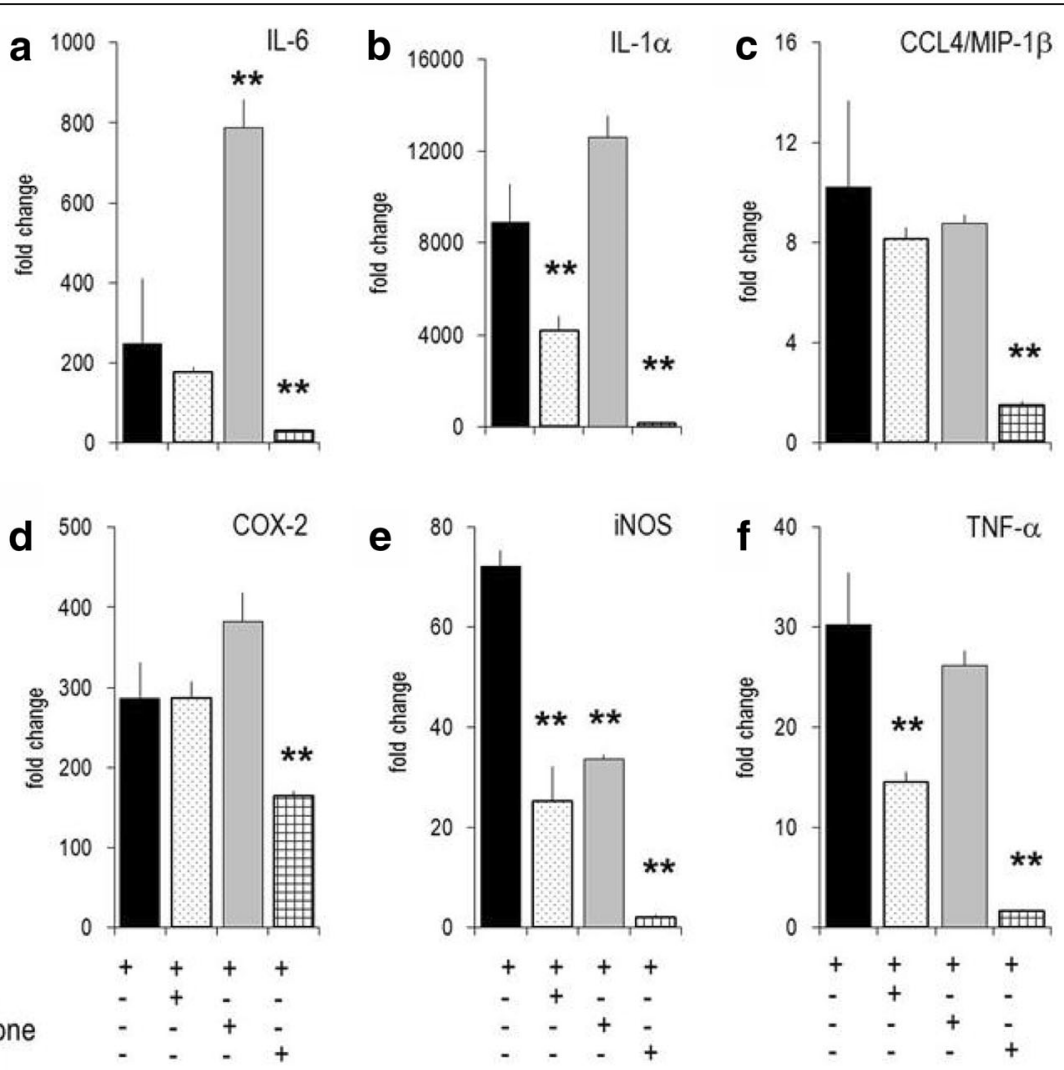

Fig. 6 Modulation of gene expression by z-ligustilide, rosiglitazone and 15d-PGJ 2 in RAW 264.7 cells. Unstimulated or LPS-stimulated RAW264.7 cells were cultured for $4 \mathrm{~h}$ in the presence of graded amounts of LIG (25 $\mu \mathrm{M})$, rosiglitazone $(25 \mu \mathrm{M})$ or $15 \mathrm{~d}-\mathrm{PGJ} \mathrm{J}_{2}(2.5 \mu \mathrm{M})$. mRNA levels were determined by RT-PCR. Bars represent mean values of fold change $+/-$ errors of triplicates (versus unstimulated cells; set at 1). ${ }^{* *} p$-value <0.01 (versus 'LPS-alone' stimulated cells). a: IL-6; b: IL-1a; c: CCL4/MIP-1ß; d: COX-2; e: iNOS; f: TNF-a

that induced adipogenesis [34, 35]. More recent data showed that PPAR $\gamma$ ligands regulated inflammatory responses by interfering with the expression of iNOS and cytokines including IL-1, TNF- $\alpha$ or gelatinase B (MMP9) in macrophages, which express the respective PPAR isoform $[4,5]$. Yet, cyclopentenone prostaglandins influenced the inflammatory responses via different signaling pathways in macrophages from PPAR $\gamma-/-$ mice [36, 37]. Conceivably, insufficient expression of PPAR isoforms in the studied cellular systems might account for the unresponsiveness to PPAR $\gamma$ ligands. Yet, PPAR $\beta$ and PPAR $\gamma$ mRNA were readily detected in RAW264.7 cells, THP-1 cells and peripheral blood leukocytes (not shown). Collectively, the data support the notion that there is an association of LIG activity and PPARy expression in macrophages; yet, this interaction is not causally related to inflammatory pathways [10, 38].

Experimental data provide a mechanistic explanation for PPAR $\gamma$-independent suppression of NF-кB by $15 \mathrm{~d}-$ $\mathrm{PGJ}_{2}[15,39]$. LIG and $15 \mathrm{~d}-\mathrm{PGJ}_{2}$ possess $\alpha, \beta$ or $\alpha, \beta, \gamma$ unsaturated carbonyl structures that react with nucleophiles including free sulfhydryl groups of glutathione or cysteine. This prevents the binding of p65 homodimers of the NF- $\mathrm{kB}$ complexes $[15,40]$ and subsequent gene activation. In the NF- $\mathrm{B}$ signaling cascade, I $\mathrm{k}$-kinase also contains cysteine residues that are prone to covalent modification. Indeed, cyclopentenone prostaglandins specifically inhibit I B degradation [15]. Importantly, since LIG and $15 \mathrm{~d}-\mathrm{PGJ}_{2}$ both have unsaturated carbonyl structures, they might share similar modes of action, as has been described for other natural substances [40, 41]. By structural analogy to $15 \mathrm{~d}-\mathrm{PGJ}_{2}$, there is evidence for a structure-activity relationship between LIG and the effect on NF- $\kappa$ B. LIG and $15 \mathrm{~d}-\mathrm{PGJ}_{2}$ might differ in their biological half-life and the propensity to bind to reactive groups, which would explain their different $\mathrm{IC}_{50}$ values. The observation that LIG reduced nuclear translocation of NF-kBp65 in LPS-stimulated cells provides additional evidence that it modulated cellular activities along the NF- $\mathrm{kB}$ signaling pathway. It should be noted that sensu stricto the immunofluoerescence data only show that LIG impaired the cytoplasmic-nuclear translocation of $\mathrm{NF}-\kappa \mathrm{B}$.

The production of most of the cytokines and chemokines was blunted by LIG in macrophages, monocytic leukemia cells (THP-1) and PBLs. Notable exceptions 

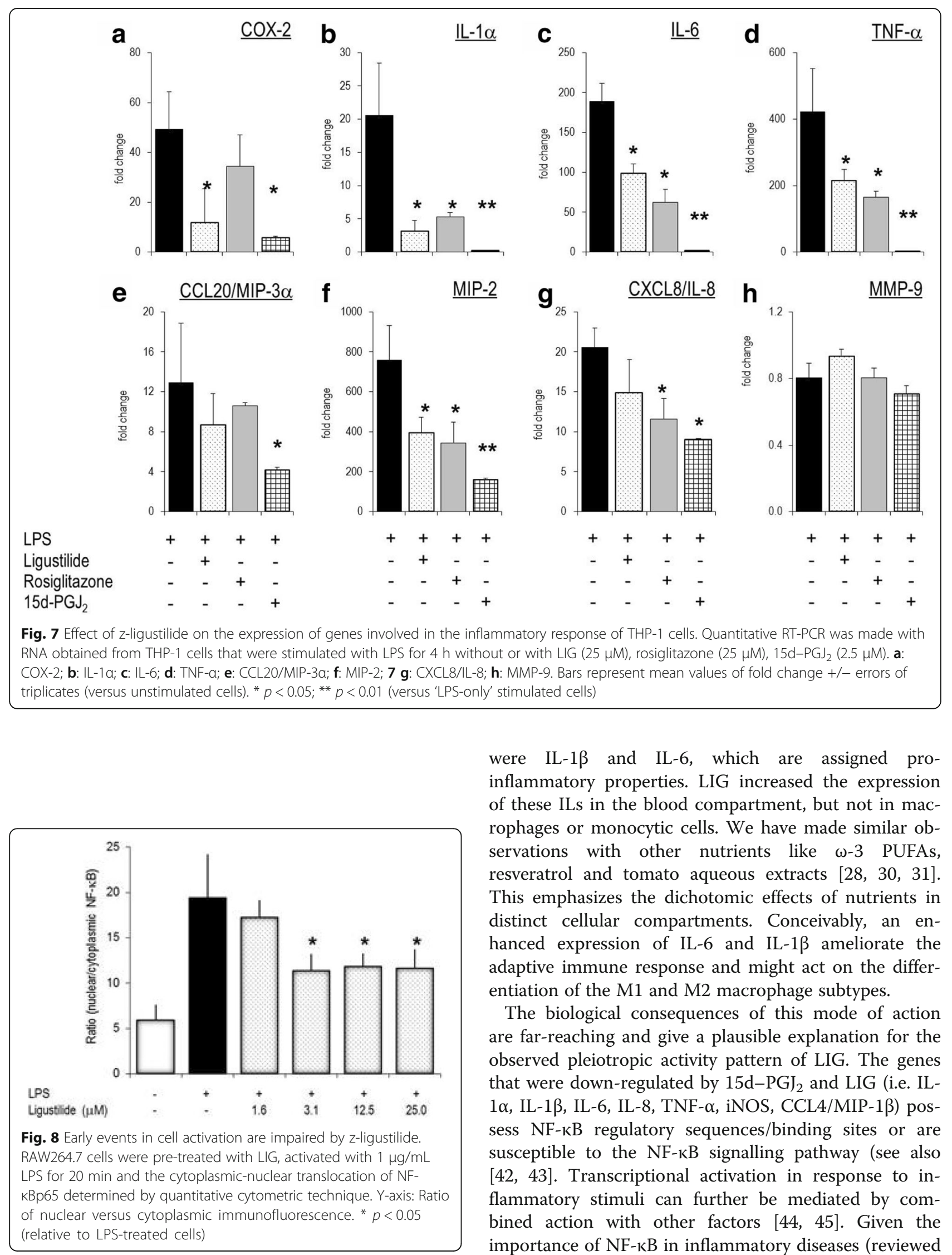

were IL-1 $\beta$ and IL-6, which are assigned proinflammatory properties. LIG increased the expression of these ILs in the blood compartment, but not in macrophages or monocytic cells. We have made similar observations with other nutrients like $\omega-3$ PUFAs, resveratrol and tomato aqueous extracts [28, 30, 31]. This emphasizes the dichotomic effects of nutrients in distinct cellular compartments. Conceivably, an enhanced expression of IL-6 and IL-1 $\beta$ ameliorate the adaptive immune response and might act on the differentiation of the M1 and M2 macrophage subtypes.

The biological consequences of this mode of action are far-reaching and give a plausible explanation for the observed pleiotropic activity pattern of LIG. The genes that were down-regulated by $15 \mathrm{~d}-\mathrm{PG} \mathrm{J}_{2}$ and LIG (i.e. IL$1 \alpha$, IL-1 $\beta$, IL-6, IL-8, TNF- $\alpha$, iNOS, CCL4/MIP-1 $\beta$ ) possess NF- $\mathrm{kB}$ regulatory sequences/binding sites or are susceptible to the NF- $\mathrm{kB}$ signalling pathway (see also $[42,43]$. Transcriptional activation in response to inflammatory stimuli can further be mediated by combined action with other factors [44, 45]. Given the importance of NF-kB in inflammatory diseases (reviewed 
in e.g. [46], even minor shifts in the amount, cellular localization or association of NF-kB elements drastically influence the outcome of the response. Admittedly, NF$\kappa \mathrm{B}$ ablation is not a panacea for inflammation, since it can result in severe apoptotic tissue damage [47]. A notable exception is the COX-2 expression in RAW264.7 cells, which remains unaffected by LIG (Fig. 5), while $\mathrm{PGE}_{2}$ production was inhibited (Fig. 1b). Concomitantly, PGES expression decreased in LIG treated cells, whereas mRNA levels of COX-2, EP-2 and PGDS were maintained. Consequently, LIG appears not to affect the part of the eicosanoid synthesis pathway that is required for the resorption of inflammation. Preserved COX-2 expression, mediated by LIG, ought to be beneficial during the resorption of inflammation when COX-2 is required for the concurrent PGDS-dependent synthesis of cyclopentenone prostaglandin $\mathrm{PGJ}_{2}$ [48].

We have demonstrated in this study that LIG, and to a larger extent $15 \mathrm{~d}-\mathrm{PGJ} \mathrm{J}_{2}$, markedly diminished the secretion of chemokines such as CXCL8/IL-8 and macrophage inflammatory proteins, CCL4/MIP-3 $\alpha$. Quantitative RT-PCR analysis revealed that the compounds attenuated the expression of these and other chemokines (CXCL1/MIP-1, CXCL2/MIP-2) by activated cells of the macrophage lineage. The CXC chemokines (e.g. murine CXCL2/MIP-2, human CXCL8/IL-8) play a role in recruitment of neutrophils, while the CC chemokine CCL4/MIP- $3 \alpha$ recruits macrophages and lymphocytes. Chemokines and cytokines are mutually induced by LPS in a specific temporal pattern with pro-inflammatory cytokines usually preceding chemokine expression. This cross-talk is controlled by NF- $\mathrm{kB}$ and relies on NF- $\mathrm{kB}$ consensus sequences in the promoter region of chemokine and cytokine genes [49-52]. Conceivably, LIG and related compounds have an indirect effect on chemokine expression e.g. through inhibition of TNF- $\alpha$ expression, which in turn affects chemokine activation. As a consequence of the versatile in vitro effects of LIG described in this study, we anticipate that LIG has in vivo activities in acute inflammation models. Indeed, LIG proved to attenuate inflammation in the carrageenan-induced paw edema model (D. Raederstorff, unpublished results). At this time, comparable studies done in human have not been published. Therefore, the effects on acute and chronic inflammation in humans needs to be established in appropriate nutritional intervention trials.

\section{Conclusions}

LIG is a potent anti-inflammatory natural substance that modulates the inflammatory response at various levels. Both by its structure and activity profile it is closely related to the cyclopentenone prostaglandins $15 \mathrm{~d}-\mathrm{PGJ}_{2}$. This confers LIG the profile of an anti-inflammatory prostaglandin that regulates the resorption of acute inflammation and blunts chronic inflammation.

\section{Additional file}

Additional file 1: Figure S1. Viability of RAW 264.7 cells after incubation with graded amounts of ligustilide, EGCG, resveratrol, 15d-PGJ2 and rosiglitazone for $24 \mathrm{~h}$. Figure S2. Regulation of inflammatory gene expression in RAW264.7 cells by ligustilide $(25 \mu \mathrm{M})$ rosiglitazone $(25 \mu \mathrm{M})$ and 15d-PGJ2 $(2.5 \mu \mathrm{M})$. Table S1. Synopsis of effects on protein secretion by (murine) macrophages or peripheral blood leukocytes (human). Table S1. Sequences of primers and probes used in quantitative real-time PCR. Table S2. Comparison of effects of $P G J_{2}$ and ligustilide on cytokines and chemokine expression. (DOCX $465 \mathrm{~kb})$

\section{Abbreviations}

CCL: Ligand of the C-C family of chemokines; CXCL: Ligand of the C-X-C family of chemokines; $I C_{50}$ : 50\% (half-maximal) inhibitory concentration; $I C_{80}: 80 \%$ maximal inhibitor concentration; IL: Interleukin; INF: Interferon;

iNOS: inducible nitric oxide synthase; LIG: Ligustilde; LPS: Lipopolysaccharide; NF-kB: Nuclear factor-kappaB; $P E_{2}$ : Prostaglandin $E_{2} ; P G J_{2}$ : Prostaglandin $J_{2} ;$ PPAR: Peroxisome proliferator-activator receptor; TNF-a: Tumor necrosis factor-a

\section{Acknowledgments}

We thank Nicole Seifert for performing the quantitative cytometric analysis for NF-KB.

Funding

Not applicable.

\section{Availability of data and materials}

These can be requested from the corresponding author.

\section{Authors' contributions}

Conceived and planned the experiments: JS, PW and IB. Performed the experiment: LG, NR and JS. Analysed and compiled the data: LG and JS Identified and provided the natural substances: WS. Reviewed and evaluated all data and wrote the manuscript: JS. All authors approved the final manuscript. This is part of LG's master work in Pharmacy.

Ethics approval and consent to participate

Not applicable.

\section{Consent of publication}

Not applicable.

\section{Competing interest}

The authors declare that they have no conflict of interest. They were employees of DSM Nutritional Products, which supported the study in the frame of a corporate program of screening for natural anti-inflammatory ingredients.

\section{Publisher's Note}

Springer Nature remains neutral with regard to jurisdictional claims in published maps and institutional affiliations.

Received: 22 May 2017 Accepted: 2 January 2018

Published online: 16 January 2018

References

1. Nathan C. Points of control in inflammation. Nature. 2002;420(6917):846-52.

2. Gilroy DW, Lawrence T, Perretti M, Rossi AG. Inflammatory resolution: new opportunities for drug discovery. Nature Rev Drug Discovery. 2004:3:401-16.

3. Willoughby DA, Moore AR, Colville-Nash PR, Gilroy D. Resolution of inflammation. Int J Immunopharmacol. 2000;22:1131-5.

4. Jiang C, Ting AT, Seed B. PPAR-gamma agonists inhibit production of monocyte inflammatory cytokines. Nature. 1998;391:82-6.

5. Ricote M, Li AC, Willson TM, Kelly CJ, Glass CK. The peroxisome proliferatoractivated receptor-gamma is a negative regulator of macrophage activation. Nature. 1998;391:79-82. 
6. Straus DS, Glass CK. Cyclopentenone prostaglandins: new insights on biological activities and cellular targets. Med Res Rev. 2001;21:185-210.

7. Colville-Nash PR, Qureshi SS, Willis D, Willoughby DA. Inhibition of inducible nitric oxide synthase by peroxisome proliferator-activated receptor agonists: correlation with induction of heme oxygenase 1. J Immunol. 1998;161:978-84.

8. Krey G, Braissant O, L'Horset F, Kalkhoven E, Perroud M, Parker MG, Wahli W. Fatty acids, eicosanoids, and hypolipidemic agents identified as ligands of peroxisome proliferator-activated receptors by coactivator-dependent receptor ligand assay. Mol Endocrinol. 1997;11:779-91.

9. Fajas L, Debril MB, Auwerx J. PPARgamma: An essential role in metabolic control. Nutr Metab Cardiovasc Dis. 2001;11:64-9.

10. Inoue M, Itoh H, Tanaka T, Chun TH, Doi K, Fukunaga Y, Sawada N, Yamshita J, Masatsugu K, Saito T, et al. Oxidized LDL regulates vascular endothelial growth factor expression in human macrophages and endothelial cells through activation of peroxisome proliferator-activated receptor-gamma. Arteriosclerosis thrombosis Vasc Biol. 2001;21:560-6.

11. Chawla A, Barak Y, Nagy L, Liao D, Tontonoz P, Evans RM. PPAR-gamma dependent and independent effects on macrophage-gene expression in lipid metabolism and inflammation. Nat Med. 2001;7:48-52.

12. Hinz B, Brune K, Pahl A. 15-deoxy-delta(12,14)-prostaglandin $J_{2}$ inhibits the expression of proinflammatory genes in human blood monocytes via a ppar-gamma-independent mechanism. Biochem Biophys Res Comm. 2003; 302:415-20.

13. Hortelano S, Castrillo A, Alvarez AM, Bosca L. Contribution of cyclopentenone prostaglandins to the resolution of inflammation through the potentiation of apoptosis in activated macrophages. J Immunol. 2000; 165:6525-31.

14. Inoue H, Tanabe T, Umesono K. Feedback control of cyclooxygenase-2 expression through PPARamma. J Biol Chem. 2000;275:28028-32.

15. Straus DS, Pascual G, Li M, Welch JS, Ricote M, Hsiang $\mathrm{CH}_{\text {, }}$ Sengchanthalangsy LL, Ghosh G, Glass CK. 15-deoxy-delta 12,14prostaglandin $\mathrm{J} 2$ inhibits multiple steps in the NF-kappab signaling pathway. Proc Natl Acad Sci U S A. 2000;97:4844-9.

16. Lee SJ, Jia Y. The effect of bioactive compounds in tea on lipid metabolism and obesity through regulation of peroxisome proliferator-activated receptors. Current Opinion in Lipidol. 2015;26:3-9.

17. Ge H, Zhang JF, Guo BS, He Q, Wang BY, He B, Wang CQ. Resveratrol inhibits macrophage expression of emmprin by activating ppargamma. Vasc Pharmacol. 2007:46:114-21.

18. Harikumar KB, Aggarwal BB. Resveratrol: a multitargeted agent for ageassociated chronic diseases. Cell Cycle. 2008;7:1020-35.

19. YW S, Chiou WF, Chao SH, Lee MH, Chen CC, Tsai YC. Ligustilide prevents LPS-induced iNOS expression in RAW 264.7 macrophages by preventing ROS production and down-regulating the MAPK, NF-KB and AP-1 signaling pathways. Int Immunopharmacol. 2011;11:1166-72.

20. Chung JW, Choi RJ, Seo EK, Nam JW, Dong MS, Shin EM, Guo LY, Kim YS. Anti-inflammator effects of (Z)-ligustilide through suppression of mitogenactivated protein kinases and nuclear factor-kB activation pathways. Arch Pharmaceutical Res. 2012;35:723-32.

21. Zhao LX, Jiang BC, XB W, Cao DL, Gao YJ. Ligustilide attenuates inflammatory pain via inhibition of NFKB-mediated chemokines production in spinal astrocytes. Eur J. Neuroscience. 2014;39:1391-402.

22. Liu L, Ning ZQ, Shan S, Zhang K, Deng T, XP L, Cheng YY. Phthalide lactones from ligusticum chuanxiong inhibit lipopolysaccharide-induced TNF-alpha production and TNF-alpha-mediated NF-kappab activation. Planta Med. 2005;71:808-13.

23. D'Orazio Di: De Saizieu A, Raederstorff D, Schueler G, Teixeira S, Wang Y, Weber $P$, Wolfram S. Use of phthalide derivative for the preparation of a pharmaceutical or dietary composition for preventing or treating diabetes mellitus. International Publication Number WO-2004/100945 A1. Publication date 25.Nov. 2004

24. Chan MM, Fong D, Ho CT, Huang HI. Inhibition of inducible nitric oxide synthase gene expression and enzyme activity by epigallocatechin gallate, a natural product from green tea. Biochem Pharmacol. 1997:54:1281-6.

25. D'Acquisto F, luvone T, Rombola L, Sautebin L, Di Rosa M, Carnuccio R. Involvement of NF-kappab in the regulation of cyclooxygenase-2 protein expression in LPS-stimulated 1774 macrophages. FEBS Lett. 1997:418:175-8.

26. Bednarski JJ, Lyssiotis CA, Roush R, Boitano AE, Glick GD, Opipari AW Jr. A novel benzodiazepine increases the sensitivity of $B$ cells to receptor stimulation with synergistic effects on calcium signaling and apoptosis. J Biol Chem. 2004;279:29615-21.
27. Bitler CM, Viale TM, Damaj B, Crea R. Hydrolyzed olive vegetation water in mice has anti-inflammatory activity. J Nutr. 2005;135:1475-9.

28. Richard N, Porath D, Radspieler A, Schwager J. Effects of resveratrol, piceatannol, tri-acetoxystilbene, and genistein on the inflammatory response of human peripheral blood leukocytes. Mol Nutr \& Food Res. 2005; 49:431-42.

29. Ding GJ, Fischer PA, Boltz RC, Schmidt JA, Colaianne JJ, Gough A, Rubin RA, Miller DK. Characterization and quantitation of NF-kappab nuclear translocation induced by interleukin-1 and tumor necrosis factor-alpha. Development and use of a high capacity fluorescence cytometric system. J Biol Chem. 1998:273:28897-905.

30. Schwager J, Richard N, Mussler B, Raederstorff D. Tomato aqueous extract modulates the inflammatory profile of immune cells and endothelial cells. Molecules. 2016;21(2):168. https://doi.org/10.3390/ molecules21020168.

31. Schwager J, Richard N, Riegger C, Salem N Jr. Omega-3 PUFAs and resveratrol differently modulate acute and chronic inflammatory processes. Biomed Res Int. 2015;535189 https://doi.org/10.1155/2015/535189.

32. Perez-Perez Gl, Shepherd VL, Morrow JD, Blaser MJ. Activation of human THP-1 cells and rat bone marrow-derived macrophages by helicobacter pylori lipopolysaccharide. Inf \& Immunity. 1995:63:1183-7.

33. Arakawa T, Laneuville O, Miller CA, Lakkides KM, Wingerd BA, DeWitt DL, Smith WL. Prostanoid receptors of murine NIH 3T3 and RAW 264.7 cells. Structure and expression of the murine prostaglandin EP4 receptor gene. J Biol Chem. 1996;271:29569-75

34. Forman BM, Tontonoz P, Chen J, Brun RP, Spiegelman BM, Evans RM. 15deoxy-delta 12, 14-prostaglandinJ2 is a ligand for the adipocyte determination factor PPAR gamma. Cell. 1995;83:803-12.

35. Kliewer SA, Lenhard JM, Willson TM, Patel I, Morris DC, Lehmann JMA Prostaglandin $\mathrm{J} 2$ metabolite binds peroxisome proliferator-activated receptor gamma and promotes adipocyte differentiation. Cell. 1995;83: 813-9.

36. Rossi A, Kapahi P, Natoli G, Takahashi T, Chen Y, Karin M, Santoro MG. Antiinflammatory cyclopentenone prostaglandins are direct inhibitors of Ikappab kinase. Nature. 2000;403:103-8.

37. Welch JS, Ricote M, Akiyama TE, Gonzalez FJ, Glass CK. PPARgamma and PPARdelta negatively regulate specific subsets of lipopolysaccharide and IFN-gamma target genes in macrophages. Proc Nat Acad Sci (USA). 2003; 100:6712-7.

38. Naitoh T, Kitahara M, Tsuruzoe $N$. The effect of activation of peroxisome proliferator-activated receptor gamma (PPARgamma) on human monocyte function: PPARgamma ligands do not inhibit tumor necrosis factor-alpha release in human monocytic cell line THP-1. Cell Biol Toxicol. 2000;16:131-5.

39. Cernuda-Morollon E, Pineda-Molina E, Canada FJ, Perez-Sala D. 15-deoxydelta 12,14-prostaglandin J2 inhibition of NF-kappab-DNA binding through covalent modification of the p50 subunit. J Biol Chem. 2001;276:35530-6.

40. Garcia-Pineres AJ, Castro V, Mora G, Schmidt TJ, Strunck E, Pahl HL, Merfort I. Cysteine 38 in p65/nf-kappab plays a crucial role in DNA binding inhibition by sesquiterpene lactones. J Biol Chem. 2001;276:39713-20.

41. Heiss E, Herhaus C, Klimo K, Bartsch H, Gerhauser C. Nuclear factor kappa b is a molecular target for sulforaphane-mediated anti-inflammatory mechanisms. J Biol Chem. 2001;276:32008-15.

42. Harant $\mathrm{H}$, de Martin R, Andrew PJ, Foglar E, Dittrich C, Lindley IJ. Synergistic activation of interleukin-8 gene transcription by all-trans-retinoic acid and tumor necrosis factor-alpha involves the transcription factor NF-kappab. J Biol Chem. 1996;271:26954-61.

43. Roebuck KA. Regulation of interleukin-8 gene expression. J Interferon \& Cytokine Res. 1999;19:429-38.

44. Lorsbach RB, Murphy WJ, Lowenstein CJ, Snyder SH, Russell SW. Expression of the nitric oxide synthase gene in mouse macrophages activated for tumor cell killing. Molecular basis for the synergy between interferongamma and lipopolysaccharide. J Biol Chem. 1993;268:1908-13.

45. Xie QW, Kashiwabara Y, Nathan C. Role of transcription factor NF-kappa b/ rel in induction of nitric oxide synthase. J Biol Chem. 1994;269:4705-8.

46. Karin M, Ben-Neriah Y. Phosphorylation meets ubiquitination: the control of NF-[kappa]b activity. Ann Rev Immunol. 2000;18:621-63.

47. Lawrence T, Gilroy DW, Colville-Nash PR, Willoughby DA. Possible new role for NF-kappab in the resolution of inflammation. Nat Med. 2001;7:1291-7.

48. Gilroy DW, Colville-Nash PR, Willis D, Chivers J, Paul-Clark MJ, Willoughby DA. Inducible cyclooxygenase may have anti-inflammatory properties. Nat Med. 1999:5:698-701. 
49. Chandrasekar B, Melby PC, Sarau HM, Raveendran M, Perla RP, Marelli-Berg FM, Dulin NO, Singh IS. Chemokine-cytokine cross-talk. The ELR+ CXC chemokine LIX (CXCL5) amplifies a proinflammatory cytokine response via a phosphatidylinositol 3-kinase-NF-kappa b pathway. J Biol Chem. 2003;278: 4675-86.

50. Sobota RM, Mueller PJ, Heinrich PC, Schaper F. Prostaglandin E1 inhibits IL6-induced MCP-1 expression by interfering specifically in IL-6-dependent ERK1/2, but not STAT3, activation Biochem J. 2008;412;65-72.

51. Cooper JA., Jr, Parks JM, Carcelen R, Kahlon SS, Sheffield M, Culbreth, R. Attenuation of interleukin-8 production by inhibiting nuclear factor-kappab translocation using decoy oligonucleotides. Biochem Pharmacol 2000;59: 605-613.

52. Sugita S, Kohno T, Yamamoto K, Imaizumi Y, Nakajima H, Ishimaru T, Matsuyama T. Induction of macrophage-inflammatory protein-3alpha gene expression by TNF-dependent NF-kappab activation. J Immunol. 2002;168: 5621-8.

Submit your next manuscript to BioMed Central and we will help you at every step:

- We accept pre-submission inquiries

- Our selector tool helps you to find the most relevant journal

- We provide round the clock customer support

- Convenient online submission

- Thorough peer review

- Inclusion in PubMed and all major indexing services

- Maximum visibility for your research

Submit your manuscript at www.biomedcentral.com/submit
Biomed Central 